\title{
Interactive interfaces applied to education: (re)creating a virtual learning scenario
}

\section{Interfaces interativas aplicadas à educação: (re)criando um cenário virtual de aprendizagem}

\author{
Willian Lima Santos ${ }^{1}$, Anne Alilma Silva Souza Ferrete ${ }^{1}$, Rosana Maria Santos Torres \\ Marcondes ${ }^{1}$
}

\begin{abstract}
Digital information and communication technologies (DICT), in an accelerated process of evolution, have been reconfiguring the way people live in society, improving communication, modifying culture and enhancing educational training processes. Constantly, new interfaces have emerged, promoting network interaction and, when used pedagogically, they can be combined to the educational process by allowing the creation of virtual learning scenarios. This study aims to present a proposal of learning scenario linked to the aspects of virtuality present in interfaces, considering its applicability in online contexts. This is a bibliographic research, which has used as theoretical contribution the studies of Dias (2012), Matos (2014), Barros, Romero and Moreira (2014), Perdigão and Santos (2018), Barros (2018), Piedade, Pedro and Matos (2018), Santos, Ferrete and Alves (2020), Santos and Ferrete (2021), Santos (2021), Santos, Ferrete and Alves (2021) to support the theme of Virtual Learning Scenarios, with a focus on the elements of interactivity, collaboration and information sharing. As a result, this study presents a scenario proposal that may be adapted to both online and offline contexts, through the devices and interfaces available in each educational reality.
\end{abstract}

Keywords: Virtual learning scenarios; Interactive interfaces; Digital information and communication technologies.

\section{RESUMO}

As tecnologias digitais de informação e comunicação (TDIC) em acelerado processo de evolução estão reconfigurando a forma como o homem vive em sociedade, aprimorando a comunicação, modificando a cultura e potencializando os processos formativos educacionais. Constantemente, surgem novas interfaces que promovem a interação em rede e, ao serem utilizadas pedagogicamente, podem ser aliadas ao processo educativo por permitirem a criação de cenários virtuais de aprendizagem. Este estudo teve como objetivo apresentar uma proposta de cenário de aprendizagem interligada aos aspectos da virtualidade presentes nas interfaces, e levando em consideração a sua aplicabilidade em contextos online. Trata-se de uma pesquisa de cunho bibliográfico, que utilizou como aporte teórico os estudos de Dias (2012), Matos (2014), Barros, Romero e Moreira (2014), Perdigão e Santos (2018), Barros (2018), Piedade, Pedro e Matos (2018), Santos, Ferrete e Alves (2020), Santos e Ferrete (2021), Santos (2021), Santos, Ferrete e Alves (2021) para fundamentar a temática dos Cenários Virtuais de Aprendizagem, com foco nos elementos da interatividade, colaboração e compartilhamento de informações. Como resultado, o estudo apresenta uma proposta de

\footnotetext{
${ }^{1}$ Universidade Federal de Sergipe (UFS).

*willianfaneb@gmail.com
} 
cenário que pode ser adaptada tanto para contextos online quanto offline, por meio dos dispositivos e interfaces disponíveis em cada realidade educacional.

Palavras-chave: Cenários virtuais de aprendizagem; Interfaces interativas; Tecnologias digitais de informação e comunicação.

\section{INTRODUCTION}

In the current context, integrating digital technologies into teaching is a necessary competence for those in the teaching profession. This idea is not as recent as it appears to be, Perrenoud (2000) in his work "Ten new competences for teaching" emphasized the didactic potential of informatics and technological resources aligned with teaching objectives, improving communication through telematics (interaction), focusing on the development of fundamental competences in a technological culture.

Although discussions on Digital Information and Communication Technologies (DICT) are expressively present in the educational field, initial teacher training courses do not significantly prepare teachers for the integration of technological and digital devices in teaching (GATTI, 2010; FRIZON, et al, 2015; SANTOS; VIEIRA; VASCONCELOS, 2021).

In the context of the New Coronavirus pandemic (Covid-19), in which physical distancing has brought about a new modality of teaching, known as Emergency Remote Teaching, the use of digital and mobile technological devices are now being used in education in a more expressive way. This modality works from the real-time interaction between students and teachers who are geographically distant in the physical space, but connected through interfaces available on the web, collaboratively building a teaching and learning process based on the elements of virtuality (ARRUDA, 2020; MOREIRA; SCHLEMMER, 2020).

From this perspective, virtual scenarios have been the facilitating spaces for interaction, collaboration and information sharing. Based on this contextualization, the main objective of this study is to present a proposal of virtual learning scenario linked to the aspects pointed out by the theoretical contribution, considering its applicability in online contexts, as a way to meet the demands of physical distancing caused by the Covid19 pandemic, in which classes have taken place in the remote format. 
Regarding the methodology, this study is based on the foundations of bibliographic research, elaborated from published material, consisting mainly of books, journals, scientific articles, newspapers, bulletins, monographs, dissertations, theses, cartographic material and internet, with the objective of promoting direct contact of the researcher with the material produced on the subject of research (PRODANOV; FREITAS, 2013).

The theoretical contribution of this work has been constructed from the perspective of Virtual Learning Scenarios in the studies of Dias (2012), Matos (2014), Barros, Romero and Moreira (2014), Perdigão and Santos (2018), Barros (2018), Piedade, Pedro and Matos (2018), Santos, Ferrete and Alves (2020), Santos and Ferrete (2021), Santos (2021), Santos, Ferrete and Alves (2021), who understand the virtual and the elements contained in it as potential resources of the learning, as long as there is pedagogical guidance for its integration in the teaching and learning process, as well as highlighting the concept and the theme of the scenarios as we are going to see throughout the text.

The development of this study has been supported by the Postgraduate Program in Education (PPGED) of the Federal University of Sergipe (UFS), through the Postgraduate Researcher Support Program (PROAP) and it has been financed by the Coordination for the Improvement of Personnel Higher Education (CAPES), through public notice No. 06/2021/PPGED/PROAP/UFS.

Through this study, we aim to contribute to the propagation of the concept of Virtual Learning Scenarios in the area of education. For this reason, we also present a scenario proposal that can be adapted to different teaching contexts, through the interfaces and digital resources that teachers and students have access to.

\section{VIRTUAL LEARNING SCENARIOS: RESIZING THE CONCEPT}

Before entering the theme of Virtual Learning Scenarios, it is necessary to consider that the term is relatively new in education researches and it is in a constant process of adaptation, seeking to keep up with the advances and evolution of digital technology related to the web functionalities, the emergence of new apps and the level of interactivity that is made possible by the interfaces.

So far, the term may be found in studies of Portuguese-speaking researchers, that is, belonging to countries whose official language is Portuguese, especially Portugal and 
Brazil. Consequently, this brings some peculiarities in the scenario format used, considering the context experienced and the available technology, meeting the same objective, which aims to enable innovation, collaboration and the sharing of experiences through the resources available in the school reality of the teacher and the student.

The first reflections on virtual learning scenarios were made by Professor Paulo Dias (2012), former chancellor of the Open University of Lisbon, in Portugal, who thought about the use of scenarios within the context of higher education, through the elements of virtuality available on smartphones, not necessarily connected to the internet. In view of the lack of access to the network in public institutions, this professor proposed a scenario format that is easily applicable in face-to-face teaching, using only the offline functions of mobile devices.

According to Dias (2012), virtual scenarios are possibilities to integrate digital technologies in teaching practice, from the interfaces and resources available to the teacher and the student. In this sense, the way they are organized, planned and used pedagogically always focus on the teaching and learning process. Moreover, they do not necessarily require internet connection, making them adaptable to remote and inclusive contexts in view of the lack of access.

The essence of the term has been evolving, as interfaces and technology in general also evolve, and it may be perceived expressively in productions published over the last few years, in which other authors have compiled the concept and resized it from the context experienced by each one. Image 1 presents, in increasing order, an overview of productions that deal with the concept of Virtual Learning Scenarios. They were mapped by Santos (2021) in his master's research, developed at the PPGED of the Federal University of Sergipe.

Image 1 - Overview of the productions that work on the concept of virtual scenarios.

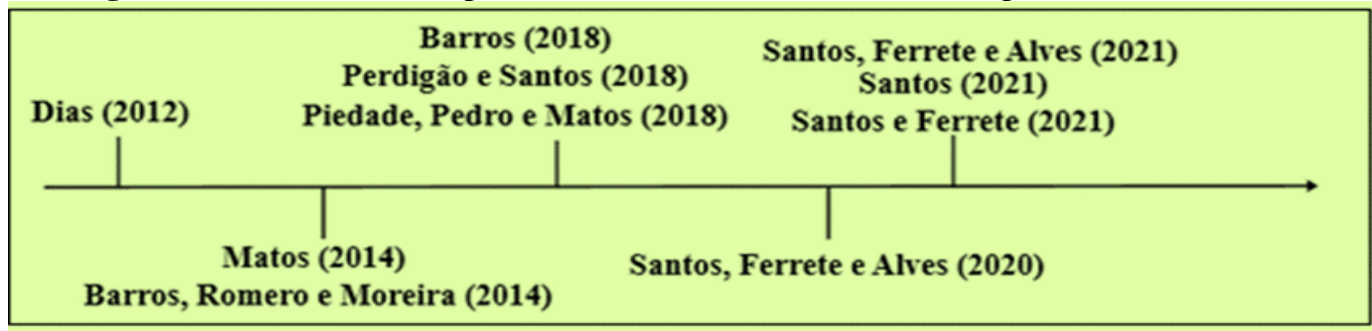

Source: Adapted by Santos (2021).

The exchange of experience in the scenario proposed by Dias (2012) took place in the context of the classroom itself, in the physical space and in real time. The rupture 
of this type of scenario appears in the studies of Matos (2014) and Barros, Romero and Moreira (2014), which bring to the theme the elements of online interactivity, the internet movement, the synchronous and asynchronous format of actions, and collaboration in the construction of network knowledge.

Still regarding the context of higher education, Barros, Romero and Moreira (2014, p. 84-85) highlight that:

The new virtual learning scenarios in higher education are based on informational spaces integrated with online virtual platforms. Colearning and its different formats are essential elements for collaborative work and collective construction of knowledge.

From this perspective, the authors mentioned above also emphasize that digital competence is the basis of the training process in the scenarios and it needs to be analyzed by teachers and students, aiming, didactically, at the development of teaching and learning around collaborative experiences. Corroborating this idea, Piedade, Pedro and Matos (2018) emphasize that the use of scenarios, as a way of planning activities, can help in the construction of competences related to problem solving, critical thinking and, above all, creativity.

Thus, Matos (2014) brought to the virtual scenarios the organizational essence, in which the roles of the actors (teachers and students) need to be aligned with educational practice, obeying a proposed working logic, with pre-established plot, in a flexible and adaptable format, according to the learning objectives. The graphic design and the way virtual is conceived and presented makes the space more dynamic and attractive. For the author, the scenarios must

[...] reflect the needs felt by teachers (how can I help my students learn using digital technologies as a support?) and count on their involvement and collaboration in the pursuit of concrete answers (MATOS, 2014, p. $15)$.

Considering the above, we can understand that the integration of digital information and communication technologies in teaching practice and, in the school context, enables the construction of new ways of teaching and learning, as long as they are aligned with the learning objectives based on methodological innovation and collaboration between the actors of the educational process (ALVES; FERRETE; 
SANTOS, 2020; MARCONDES; FERRETE, 2020; ALVES; SOBRAL; SANTOS, 2020).

In addition, on the prism of technological devices in education, Barros (2018) draws attention to the use of Open Educational Resources (OER), which are free informal interaction services available on the web, such as games, websites, social networks and apps in general. Furthermore, this author also analyzes how such services may be rethought and organized pedagogically for the teaching and learning purposes, from the constitution of meanings in order to construct a collaborative knowledge in a network, by means of interactivity, intentionality and directions made by teachers and students.

The gratuitousness of the OER makes these scenarios most widely used by the connected users, also allowing the creation of content, the sharing of services and the instant flow of information, photos, videos, music, etc., as it happens expressively in social media (social networks). Perdigão and Santos (2018), in their study, propose the recreation of interactive spaces (virtual scenarios) from gamification and the elements present in games, aiming at the construction of a playful space and the promotion of learning.

Corroborating the authors in this field of social media, Santos, Alves and Ferrete (2020) discuss the use of Facebook as a virtual scenario that facilitates communication and interaction, enabling the creation of online communities, based on learning objectives, as well as the enjoyment and personal interest of each user and their permanence in this network.

Although the use of social networks, apps and games, or rather, the use of digital technology in general had been something little explored in the public educational context due to the factors that hinder internet access and the lack of digital devices, as well as failures in the preparation and initial training of teachers for the integration of DICT in teaching practice, the use begins to occur more expressively in the pandemic, as a consequence of physical distancing and the implementation of Emergency Remote Teaching (SANTOS, 2021; SANTOS; FERRETE; 2021; SANTOS; FERRETE; ALVES, 2021).

Because of the pandemic context, online has become an alternative space for educational practices, expanding the possibilities of using virtual scenarios and being the guideline for interaction and collaboration. Inevitably, due to the Emergency Remote Teaching, teachers and students of various modalities and levels of education, from public 
and private institutions, have begun to experience the integration of DICT in the construction of learning, obviously, within the particularities of each institution, region and target audience.

Therefore, we draw attention to the flexible and adaptable characteristic of Virtual Learning Scenarios, the way the concept has been resized over the years according to technological evolution and the context that is being experienced by society.

From this perspective, Santos (2021) lists the new characteristics of the scenarios that have been used in Emergency Remote Teaching, within the scope of his research developed in the municipality of Jeremoabo/BA, as we can see below in image 2 .

Image 2 - Characteristics of the new Virtual Learning Scenarios.

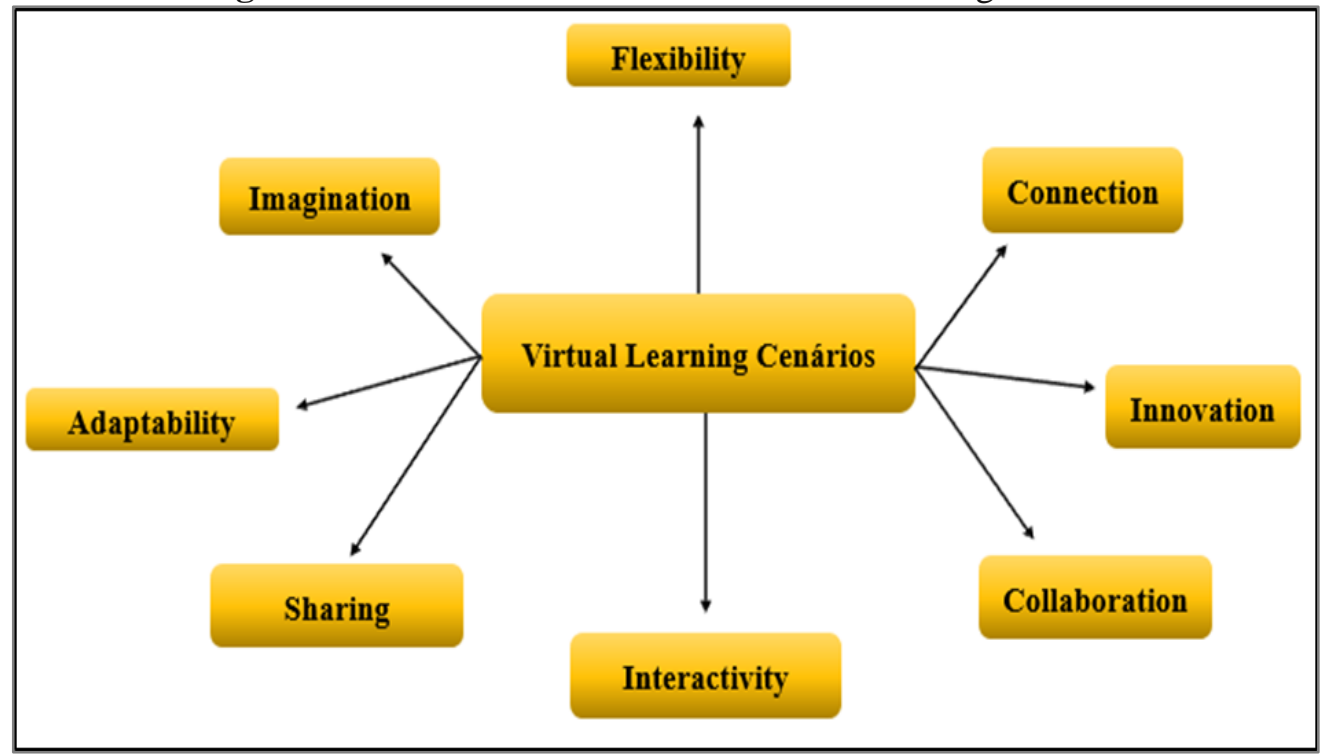

Source: Adapted by Santos (2021).

According to the author previously mentioned, when contemplating these main characteristics, virtual scenarios will become potential didactic and pedagogical instruments for the construction of knowledge in a network. In this sense, they are flexible since their objectives keep on changing and, besides that, they are also adaptable in order to meet the demands of different teaching contexts. Based on this perspective, Santos (2021) thought about the adaptability of virtual scenarios for the teaching practice in the field of elementary school, bringing discussions to the field of languages as well. In this context, it is emphasized that the idea of scenarios has been designed for higher education environments, but the elements that compose them may be adapted to other educational realities. 
Sharing, interaction and collaboration are necessary elements so that the permanence of the teacher and the student in the virtual scenario makes sense, in order to build a space for exchanging experiences. Connection allows navigation using other environments, with other features that may be managed and gathered in the scenario, promoting innovation and imagination, making it more dynamic and attractive.

In this sense, Santos, Ferrete and Alves (2021, p. 08) highlight that:

\begin{abstract}
Virtual scenarios are broad and constituted by actions and resources that can become pedagogical from the intentionality attributed to the teaching practice, favoring collaborative sharing in the face of the teaching and learning process, through the interaction between those involved in the virtual.
\end{abstract}

Therefore, in the current context reconfigured by the pandemic, such scenarios have been facilitating elements of connection among families, institutions, teachers and students, considering the available technologies and interfaces that have been easily accessible to the actors of this educational process.

This integration goes beyond the pragmatic use of digital technology in education, since it focuses on its various possibilities of use for learning, interaction, communication and collaboration. From this point of view, virtual scenarios can strengthen the educational process, as long as it is well aligned with the pedagogical proposal of the system, the school and the teachers themselves.

\title{
PROPOSAL FOR A VIRTUAL LEARNING SCENARIO
}

This section presents a proposal for a Virtual Learning Scenario which can be used and adapted for both online and offline context, and also for any modality or level of education, through the integration of the internet network with available mobile and digital technology, such as smartphones, notebooks, tablets or other resources.

Despite the possibility of being applied in any context by the means of the available technologies, this scenario proposal was designed for the context of Emergency Remote Teaching, considering that, as a result of the worsening of the pandemic, online within virtual has been constituted as an educational space due to the dire need to maintain the physical distancing between people as a way to avoid agglomerations and the proliferation of the virus. 
Image 3 presents a proposal for the virtual learning scenario, developed by these researchers, which was based on accessible elements and available on Google Slides, a free online service integrated into the $\mathrm{G}$ Suite For Education platform tools package (Google tools). This scenario is available on Google Drive, under the rule of the researcher, and it can be accessed by any person either via the link <http://gg.gg/nh7fq $>$ or via the Qr Code located in the lower right corner of the image.

Image 3 - Proposal for a Virtual Learning Scenario.

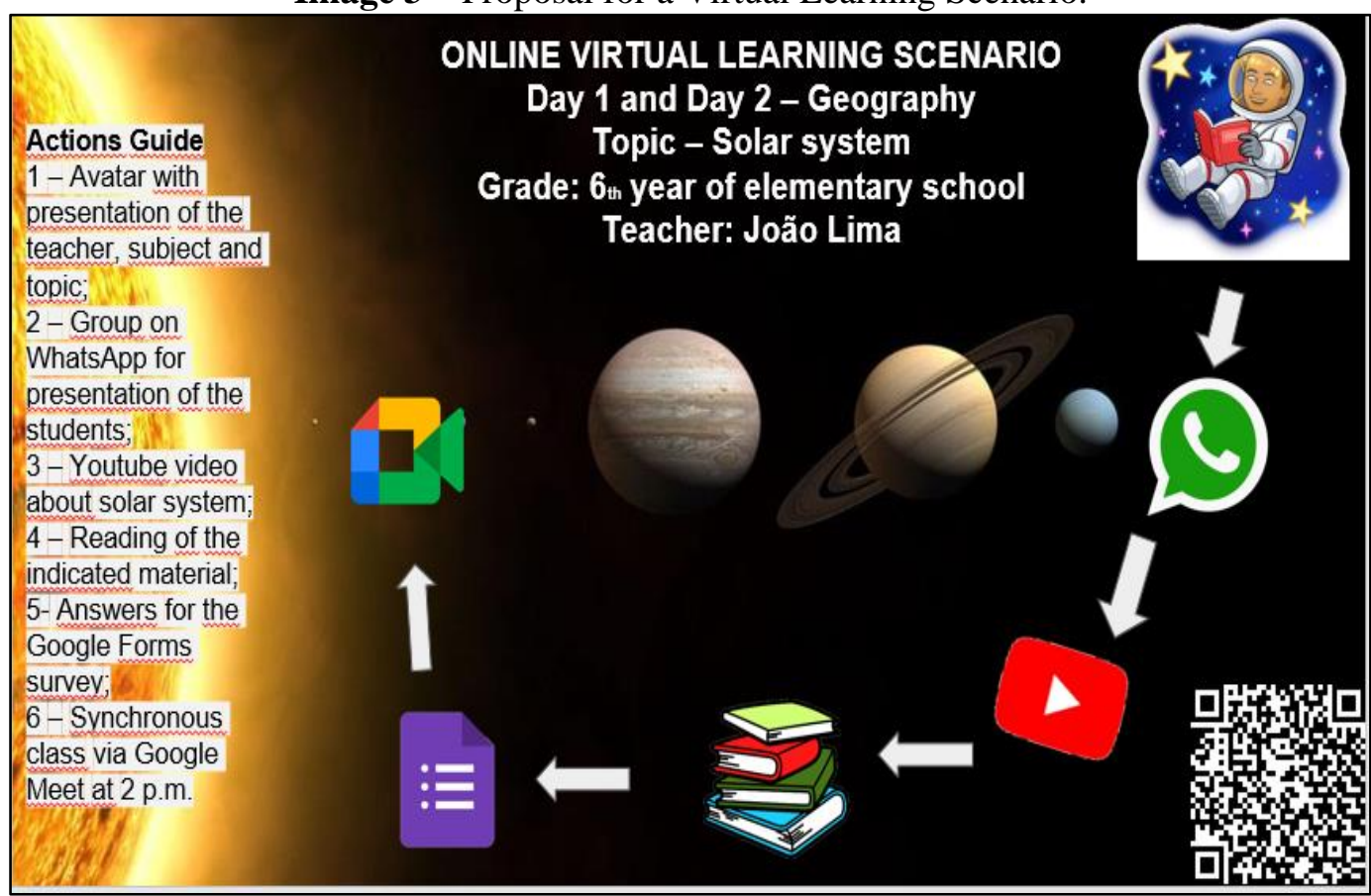

Source: Prepared by the authors (2021).

This scenario was constructed for demonstrative purposes, aiming to show different ways of using interfaces in the teaching and learning process. This presentation represents a Geography class, which was planned from the perspective of Emergency Remote Teaching, however these digital resources can also be used in face-to-face teaching.

It is worth mentioning that the teaching/learning sequence or activities guide is an important element in the virtualized teaching practice as a way to guide students in the face of the actions to be developed in the Virtual Learning Scenarios.

The development of this type of scenario, based on the foundations of this scientific research, has arisen from the extension actions carried out by the Research Center on Communication and Technology (NUCA) of the Federal University of Sergipe 
(UFS). The initial proposal was to create clickable virtual environments that would enable their use both in the contexts of remote classes and in the face-to-face teaching.

This type of scenario allows the integration of several other interfaces of free choice, in order to promote greater engagement and interaction of students with digital technology, in view of the activities and actions that may be carried out and integrated into the environment. This also allows the teacher to innovate regarding the use of tools, exploring the elements available in each scenario (app, website, blog, game or social network).

Whether it is to present syllabi or to guide students to perform tasks, as in the example previously illustrated, this type of scenario allows practical adaptations so that it may be used in any context (online or offline), as long as it is aligned with the teacher's objectives in the process of teaching and learning.

In practice, this scenario can be easily organized by the teacher. The first step is the lesson plans about the content that will be addressed, the interfaces which will be used and the actions to be developed by the students. The scenario itself is extremely adaptable, allowing the integration of new activities that might arise throughout the process.

After finishing the lesson plans and also the activities guide that will be carried out in the scenario, it is time to organize the virtual space. This organization occurs in four steps, as shown in Image 4.

Image 4 - Steps for creating the Virtual Scenario in Google Slides

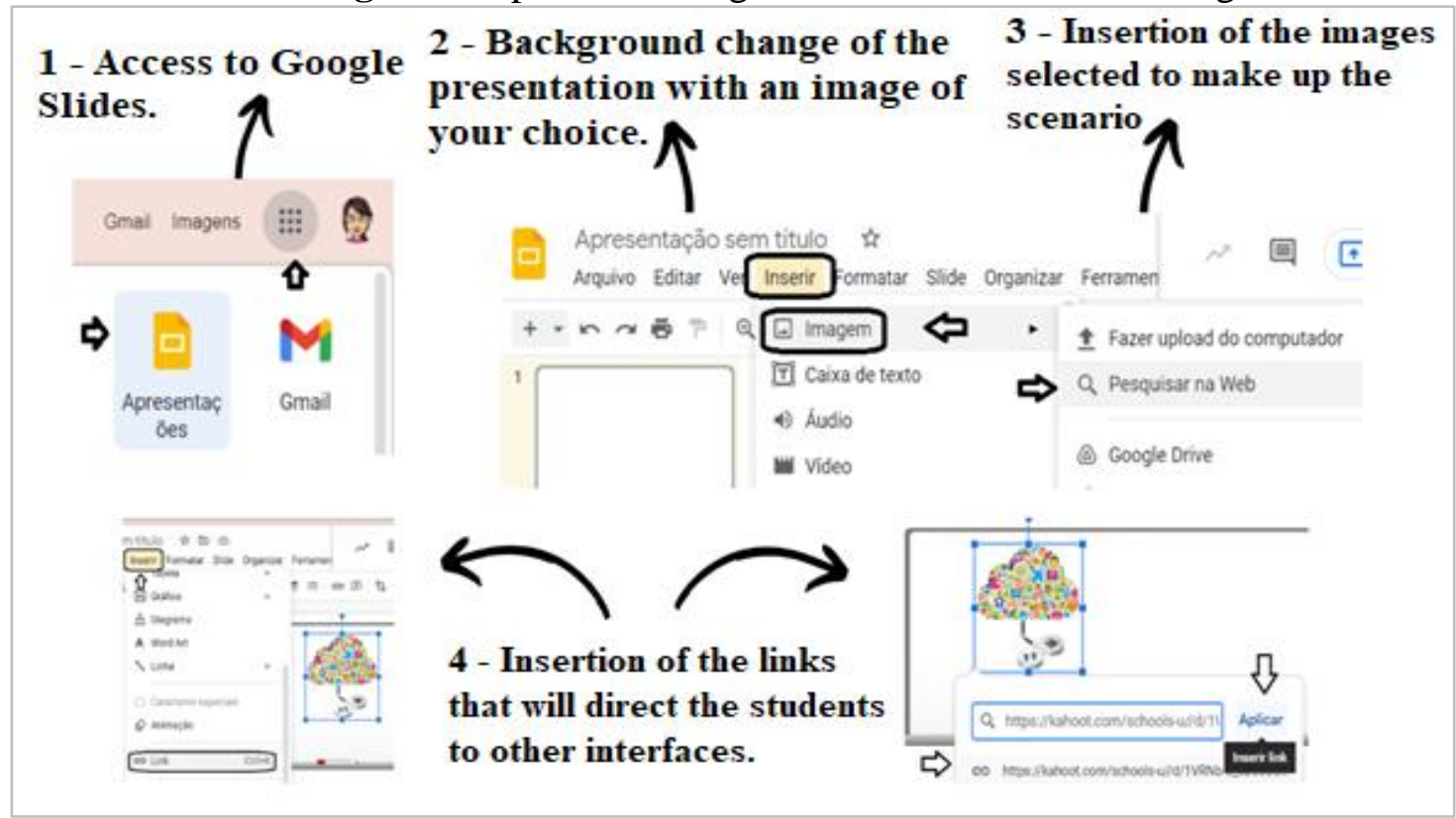

Source: Prepared by the authors (2021). 
When handling the features available on Google Slides, changes will be automatically saved; thus, after the online scenario is assembled, it will be available on Google Drive and also ready to be shared in a variety of formats, such as PDF, Word or PowerPoint. The file can be easily emailed and it is also made available in online communities by the means of links or Qr Code.

Another advantage is the factor of inclusion that this type of scenario can provide, considering realities such as the rural area of Jeremoabo, where students have to deal with network access limitations, since the files available in the scenario, such as texts, music, videos, can be easily shared on smartphones via Bluetooth, even without network access. This peculiar characteristic makes these scenarios easily applicable and also adaptable to different contexts.

With this proposal for a scenario, this study aims to expand the discussions about the numerous possibilities of using Virtual Learning Scenarios in education as a way to encourage and innovate teaching practice in different teaching contexts, which can be either face-to-face, remote or teaching/learning distance modality $(\mathrm{EaD})$. The innovation mentioned here refers to methodological issues, considering that the use of new digital resources also requires a new teaching approach, such as the integration of active methodologies, which conceive the student as the center of learning, that is, as a participative being and also a builder of their own knowledge (MARCONDES; FERRETE; SANTOS, 2021).

Without this innovation, even in an online scenario, the teaching and learning process will remain idle, without alternation and there will be little engagement from the students in the educational practice in process. In this sense, it is emphasized that the central issue involved in the research interests is not only whether or not teachers can master the digital technology, but rather to understand how teachers are using this technology in their teaching practice based on how they already handle it.

\section{FINAL REMARKS}

Based on the theoretical contribution analyzed, and conceiving the main characteristics presented by the authors in their productions, regarding the evolution of digital technologies and the interactive interfaces available on the web, this study delivers to the scientific community and society in general a proposal for a virtual learning scenario, which can be organized and adapted to meet the demands of several 
educational contexts, enabling, in a simple way, the integration of the DICT and their elements for teaching and learning purposes.

The research has demonstrated distinct conceptions and concepts about virtual learning scenarios according to the specificities of the contexts in which the studies have been conducted, in order to review the peculiarities of each reality, technological advances and the features available in the interfaces. Besides that, the integration of online has been considered as a fundamental element in the period of physical distancing according to the need for instant interaction and collaboration between teachers and students in Emergency Remote Teaching.

We emphasize that the idea of working with virtual scenarios is not directly linked to the type of technological resource that will be used in teaching practice, because, at any rate, it is necessary to consider the interfaces that the school actors might have access to, those ones they like to use the most, and also those ones the teacher finds it easier deal with. In other words, the focus should not be on the apps (or other interfaces), but on the features they perform and how these features may be used pedagogically in favor of the teaching and learning process and, thus, they can be adapted to various contexts.

However, we emphasize the need for teacher training focused on the use of digital technologies in educational practice, so that teachers are prepared to integrate devices and interfaces in their classes in order to meet the demands of today's society, especially in this current scenario that we are experiencing at the moment, in which the DICT have been essential for the continuation of education, either in face-to-face, remote or hybrid format.

\section{ACKNOWLEDGEMENTS}

We would like to extend our thanks to the Coordination for the Improvement of Personnel Higher Education (CAPES) and the Posgraduate Program in Education (PPGED/UFS) for the encouragement and financial support which has been essential for the development of this study.

\section{REFERENCES}

ALVES, M. M. S.; FERRETE, A. A. S. S.; SANTOS, W. L. As tecnologias móveis digitais de informação e comunicação presentes na formação inicial docente em 
ciências biológicas. Revista Tear, Porto Alegre, v. 9, n. 2, p. 01-20, 2020. Disponível em: https://doi.org/10.35819/tear.v9.n2.a4520. Acesso em: 01 set. 2021.

ALVES, W. S.; SOBRAL, D. A. P. S.; SANTOS, W. L. O aplicativo WhatsApp como recurso pedagógico no ensino da Língua Portuguesa. Revista FSA, Teresina, v. 17, n. 10, art. 17, p. 326-341, 2020. Disponível em:

http://www4.unifsa.com.br/revista/index.php/fsa/article/view/2099. Acesso em: 01 set. 2021.

ARRUDA, E. P. Educação remota emergencial: elementos para políticas públicas na educação brasileira em tempos de COVID-19. Revista Em Rede, Porto Alegre, v. 7, n. 1, p. 257-275, 2020. Disponível em:

https://www.aunirede.org.br/revista/index.php/emrede/article/view/621. Acesso em: 01 set. 2021.

BARROS, D. M. V. Novos Cenários Virtuais de Aprendizagem. 2018. (02m43s).

Disponível em: https://youtu.be/PqipWMJAh7k. Acesso em: 01 set. 2021.

BARROS, D. M. V.; ROMERO, C. S.; MOREIRA, J. A. Cenários Virtuais de Aprendizagem, colaboração e intercâmbio: a coaprendizagem como uma estratégia didático pedagógica. Tempos e Espaços em Educação, São Cristóvão, v. 7, p. 77-88, 2014. Disponível em: https://seer.ufs.br/index.php/revtee/article/view/3453. Acesso em: 25 abr. 2021.

DIAS, P. Comunidades de educação e inovação na sociedade digital. Educação, Formação \& Tecnologias, Monte de Caparica, v. 5, n. 2, p. 3-9, 2012. Disponível em: https://dialnet.unirioja.es/descarga/articulo/5021353.pdf. Acesso em: 01 set. 2021.

GATTI, B. A formação de professores no Brasil: características e problemas. Educação \& Sociedade, Campinas, v. 31, p. 1355-1379, 2010. Disponível em: https://www.scielo.br/pdf/es/v31n113/16.pdf. Acesso em: 30 abr. 2021.

FRIZON, V. Et al. A formação de professores e as tecnologias digitais. In: EDUCERE Encontro Nacional sobre Atendimento Escolar Hospitalar, n. 12, 2015, Paraná. Anais... Cidade Universitária: PUCPR, 2015, p. 10191-10205. Disponível em: http://educere.bruc.com.br/arquivo/pdf2015/22806_11114.pdf. Acesso em: 02 set. 2021.

MARCONDES, R. M. S. T.; FERRETE, A. A. S. S. Tecnologia digital de informação e comunicação e metodologias ativas na personalização do ensino de redação. Revista Humanidades e Inovação, Palmas, v. 6, n. 6, p. 207-220, 2020. Disponível em: https://revista.unitins.br/index.php/humanidadeseinovacao/article/view/2314/1527. Acesso em: 01 set. 2021.

MARCONDES, R. M. S. T.; FERRETE, A. A. S. S.; SANTOS, W. L. Tecnologia Digital de Informação e Comunicação como recurso pedagógico no ensino da Língua Portuguesa. Revista Fólio, Vitória da Conquista, v. 13, n. 1, p. 861-878, 2021. Disponível em: https://periodicos2.uesb.br/index.php/folio/article/view/7978/6078. Acesso em: 09 nov. 2021. 
MATOS, J. F. Princípios orientadores para o desenho de Cenários de Aprendizagem. 2. ed. Instituto de Educação. Lisboa: Universidade de Lisboa. 2014.

MOREIRA, J. A.; SCHLEMMER, E. Por um novo conceito e paradigma de educação digital onlife. Revista UFG, Goiânia, v. 20, p. 01-35, 2020. Disponível em: https://www.revistas.ufg.br/revistaufg/article/view/63438/36079. Acesso em: 01 set. 2021.

PERDIGÃO, E.; SANTOS, F. Recriando um cenário virtual de aprendizagem: análise de jogo educativo em um curso a distância. In: Colóquio Brasileiro de Ensino Superior à Distância, n. 15, p. 01-13, 2018. Natal. Anais... Universidade Federal do Rio Grande do Norte. Disponível em: https://esud2018.ufrn.br/wp-content/uploads/187319_1ok.pdf. Acesso em: 01 set. 2021.

PERRENOUD, Philippe. Dez novas competências para ensinar. Porto Alegre: Artmed, 2000.

PIEDADE, J.; PEDRO, A.; MATOS, J. F. Cenários de aprendizagem como estratégia de planificação de aulas na formação inicial de professores: o exemplo da área de informática. In: Congresso Internacional de TIC e Educação, 5., 2018, Lisboa. Anais.. Instituto de Educação da Universidade de Lisboa: 2018 p. 1833-1851. Disponível em: http://ticeduca.ie.ul.pt/atas/atas_te_2018.pdf. Acesso em: 04 abr. 2021.

PRODANOV, C. C.; FREITAS, E. C. Metodologia do trabalho científico: métodos e técnicas da pesquisa e do trabalho acadêmico. Novo Hamburgo, RS: Feevale, 2013.

SANTOS, W. L. Cenários Virtuais de Aprendizagem como interfaces didáticopedagógicas no Ensino Fundamental. 2021. Dissertação (Mestrado em Educação) Programa de Pós-Graduação em Educação da Universidade Federal de Sergipe. São Cristóvão, 2021.

SANTOS, W. L.; FERRETE, A. A. S. S. A integração das tecnologias digitais de informação e comunicação no Ensino Remoto Emergencial em Jeremoabo-BA. Revista Cocar, Belém, v. 15, n. 32, p. 01-20, 2021. Disponível em: https://periodicos.uepa.br/index.php/cocar/article/view/4280. Acesso em: 01 set. 2021.

SANTOS, W. L.; FERRETE, A. A. S. S.; ALVES, M. M. S. Cenários virtuais de aprendizagem como recurso pedagógico diante da pandemia do novo coronavírus: relatos das experiências docentes. Revista Educação, Santa Maria, v. 46, p. 01-27, 2021. Disponível em: https://periodicos.ufsm.br/reveducacao/article/view/44201. Acesso em: 01 set. 2021.

SANTOS, W. L.; FERRETE, A. A. S. S.; ALVES, M. M. S. A produção do conhecimento sobre Facebook e educação no portal de periódicos da CAPES: relatos de experiências docentes. Revista Exitus, Santarém, v. 10, p. 01-28. Disponível em: http://www.ufopa.edu.br/portaldeperiodicos/index.php/revistaexitus/article/view/1255/6 91. Acesso em: 09 abr. 2021. 
SANTOS, W. L.; VIEIRA, A. R. L.; VASCONCELOS, C. A. Digital technology and education: mapping productions in scientific journals. Revista Ciências Humanas, Taubaté, v. 14, p. 01-11. Disponível em:

https://www.rchunitau.com.br/index.php/rch/article/view/766/412Acesso em 12 nov. 2021.

Recebido em: 20/01/2022

Aprovado em: 21/02/2022

Publicado em: 24/02/2022 